\title{
François de La Mothe le Vayer, De la liberté et de la servitude
}

Daniela Dalla Valle

\section{(2) OpenEdition}

Journals

\section{Edizione digitale}

URL: http://journals.openedition.org/studifrancesi/9183

DOI: 10.4000/studifrancesi.9183

ISSN: 2421-5856

\section{Editore}

Rosenberg \& Sellier

\section{Edizione cartacea}

Data di pubblicazione: 1 juin 2008

Paginazione: 179

ISSN: 0039-2944

\section{Notizia bibliografica digitale}

Daniela Dalla Valle, «François de La Mothe le Vayer, De la liberté et de la servitude», Studi Francesi

[Online], 154 (LII | I) | 2008, online dal 30 novembre 2015, consultato il 10 janvier 2021. URL: http:// journals.openedition.org/studifrancesi/9183; DOI: https://doi.org/10.4000/studifrancesi.9183

Questo documento è stato generato automaticamente il 10 janvier 2021.

\section{(c) $(7)$}

Studi Francesi è distribuita con Licenza Creative Commons Attribuzione - Non commerciale - Non opere derivate 4.0 Internazionale. 


\title{
François de La Mothe le Vayer, De la liberté et de la servitude
}

\author{
Daniela Dalla Valle
}

NOTIZIA

FRANÇOIS DE LA MOTHE LE VAYER, De la liberté et de la servitude, édition et postface de Lionel LEFORESTIER, Paris, Gallimard, Le Promeneur, 2007, pp. 109.

Riedizione moderna del volumetto di La Mothe Le Vayer (pubblicato nel 1643), che Leforestier commenta in una breve postfazione (pp. 97-108). È importante questa riproposta ai lettori moderni di un testo così interessante di uno dei più notevoli scrittori del 'libertinage érudit'; Leforestier percorre rapidamente la vita dell'autore e il senso particolare di quest'opera. Il testo è modernizzato, i riferimenti che La Mothe Le Vayer dava in margine sono precisati e inseriti in nota. 